\title{
Protein Profile Characterization of Donkey Milk
}

\author{
Paolo Polidori and Silvia Vincenzetti
}

Additional information is available at the end of the chapter

http://dx.doi.org/10.5772/45982

\section{Introduction}

Milk is a biological fluid designed to contain all nutritional requirements of a specific mammalian newborn; therefore, the composition of milk differs by the needs of the neonate of different species. Although much research has been devoted to milk composition in the domestic horse, donkey's milk has recently aroused scientific interest, above all among paediatric allergologists and nutritionists. Clinical studies have demonstrated that donkey milk may be considered a good replacer for dairy cow's milk in feeding children with severe Ig-E mediated cow's milk protein allergy, when human milk can not be given [1]. For these patients, donkey milk is not only useful [2], but also safer compared with milk obtained by other mammalian species [3], due to the high similarity with human milk, especially considering protein fractions content $[4,5]$.

\section{Milk proteins}

In 1838, a Swedish scientist called Jacob Berzelius suggested the term "protein" after the greek word "proteios", which means "primary" or "of the first rank"; since then, many scientific discoveries have been made about these large molecules indispensable for the good functioning of the body's cells, tissues and organs. In the past, it was believed that the function of proteins was restricted to tissue-formation, while carbohydrates and lipids provided energy to the body. Another out-of-date concept was the belief that dietary proteins were completely hydrolyzed in the gastro-intestinal tract and only free amino acids could be adsorbed from the gut. The new concept is that macro- and microelements (such as vitamins and minerals) may interact to perform different functions in the body [6]; amino acids and peptides formed in the digestion of natural proteins are adsorbed and incorporated (anabolism) into various tissues and organs as body proteins.

Milk protein is a very heterogeneous group of molecules and, for ease description, could be classified into five main categories: caseins, whey proteins, milk fat globule proteins, 
enzymes and other miscellaneous minor proteins [7]. Milk proteins appear to be an exciting link between nutrition, dietetics and therapy; today, consumers can expect more than just nutrition from intake of milk proteins. In fact, milk contains a variety of bioactive compounds with special properties associated with the development, growth and survival of infants beyond those provided by nutrition alone [8]. The major antimicrobial proteins in milk are immunoglobulins, lactoferrin, lactoperoxidase and lysozyme [9]. Immunoglobulins (IgG, IgM and secretory IgA) act by a specific mode of action involving antigen-antibody reactions. The other three proteins are non-specific protective factors, and their antimicrobial mechanisms of action differ from each other.

Lactoferrin, also called lactotransferrin, is an iron binding protein present in milk, saliva, tears and mucus secretions, its bacteriostatic effects are usually attributed to lactoferrin's ability to bind environmental iron ions. Lactoferrin inhibits the growth of many kinds of Gram-negative and Gram-positive bacteria as well as some species of fungi and yeast [9]. Lactoperoxidase, a heme-containing protein, catalyzes an oxidation reaction involving hydrogen peroxide $\left(\mathrm{H}_{2} \mathrm{O}_{2}\right)$ and functions as a component of host defense system. The lactoperoxidase system is known to be effective to preserve raw milk without refrigeration and it is used in the production of many dairy products [10].

Lysozyme exerts its antimicrobial activity by the hydrolysis of glycosidic bonds of mucopolisaccarides in bacterial cell walls [11]. Lysozyme, together with other peptides including immunoglobulins, lactoferrin and lactoperoxidase, is active in the infant's digestive tract in order to reduce the incidence of gastro-intestinal infections [12].

\section{Cow milk allergy}

Food allergy is the clinical syndrome resulting from sensitization of an individual to dietary proteins or other food allergens present in the intestinal lumen [13]. Food allergy is much more common among children than adults, and is more common among younger children than older children [14]. Cow Milk Allergy (CMA) is a frequent disease in infants, but its etiologic mechanisms are not clear [15]. Clinical symptomology for patients allergic to bovine milk proteins include: rhinitis, diarrhea, vomiting, asthma, anaphylaxis, urticaria, eczema, chronic catarrh, migraine, colitis and epigastric distress. Cow milk allergy is clinically an abnormal immunological reaction to cow milk proteins, which may be due to the interaction between one or more milk proteins and one or more immune mechanisms, and resulting in immediate IgE-mediated reactions [16]. On the other side, reactions not involving the immune system are defined as cow milk protein intolerance.

Cow milk is one of the most common food allergies in children, occurring in between 0.3 and $7.5 \%$ of the infant population [17]. The clinical diagnosis of milk allergy differs widely due to the multiplicity of symptoms. Cow milk contains more than 20 proteins (allergens) that can cause allergic reactions [18]. The main proteins are casein and whey protein; casein is fractionated into $\alpha-, \beta$ - and k-casein, whey proteins include $\alpha$-lactalbumin, $\beta$ lactoglobulin, bovine serum albumin (BSA) and immunoglobulin (Igs). In addition to those, 
several minor proteins are also present in cow milk. Most studies revealed that casein and $\beta$ lactoglobulin are the main allergens in cow milk. The type of immune response after intrusion of foreign proteins is extremely variable, depending on the animal species, the age of the host, the quality and the quantity of antigens absorbed, the location of the absorption, the pathophysiological state and the genetic background [19].

For human beings cow's milk represents the most common feeding during the infant weaning, but also the first allergen in life. The European Academy of Allergy and Clinical Immunology distinguishes allergy from intolerance [20]. Allergy is an adverse reaction to food with an involvement of the immune system; intolerance is an adverse reaction to food that does not involve the immune system, does not reply to a precise and single fault and shows different symptoms. In many countries cow's milk is the most important food allergen in babies and children [21]. Adverse reactions to cow's milk were found in $2 \%$ of babies during the first year of life: $30 \%$ of cases at the first month, $60 \%$ before the third and $96 \%$ within the twelfth $[22,23]$. Symptoms can even appear during the breast-feeding because newborn reacts against a small amount of cow milk proteins present in maternal milk [24]. Children followed for the first 3 years of life, $56 \%$ of cases had recovered from cow's milk allergy at 1-year age, $77 \%$ at 2 years and $87 \%$ at 3 years age [25] (Host and Halken, 1990). However allergy can persist for all life.

Considering the possible use of alternative milk sources for human in cases of cow's milk allergy, the use of goat's milk should be avoided because of the high risk of cross-reactivity , while mare's and donkey's milks, used in popular practice for allergic children, are valid alternative protein sources when appropriately evaluated from the hygienic point of view [26].

\section{Donkey milk}

The donkey (Equus asinus) is a member of the horse family and its progenitor was the small gray donkey of northern Africa (Equus africanus) domesticated around $4000 \mathrm{BC}$ on the shores of the Mediterranean Sea. It worked together with humans for centuries; the most common role was for transport. It still remains an important work animal in the poorer Regions.

Compared with ruminant's milk, donkey milk has been studied less in the past, but in the last years research interest and capital investment in donkey milk have increased because its composition is similar to that of human milk (see Table 1).

The protein composition is significantly different from cow's milk: the total content is lower $(13-28 \mathrm{mg} / \mathrm{ml})$ and quite similar to that of human and mare milk: this condition avoids an excessive renal load of solute [28]. The main difference is the proportion of whey proteins: they are $35-50 \%$ of the nitrogen fraction while they represent only $20 \%$ in cow's milk [29]. Comparing donkey's and mares milk, the casein to whey protein ratio in mares milk is $0.2: 1$ immediately post-partum, and changes to 1.2:1 during the first week of lactation [30]. 


\begin{tabular}{|c|c|c|}
\hline & Donkey & Human \\
\hline $\mathrm{pH}$ & $7.0-7.2$ & $7.0-7.5$ \\
\hline Protein $(\mathrm{g} / 100 \mathrm{~g})$ & $1.5-1.8$ & $0.9-1.7$ \\
\hline Fat $(\mathrm{g} / 100 \mathrm{~g})$ & $0.3-1.8$ & $3.5-4.0$ \\
\hline Lactose $(\mathrm{g} / 100 \mathrm{~g})$ & $5.8-7.4$ & $6.3-7.0$ \\
\hline Ash $(\mathrm{g} / 100 \mathrm{~g})$ & $0.3-0.5$ & $0.2-0.3$ \\
\hline Total Solids $(\mathrm{g} / 100 \mathrm{~g})$ & $8.8-11.7$ & $11.7-12.9$ \\
\hline Caseins $(\mathrm{g} / 100 \mathrm{~g})$ & $0.64-1.03$ & $0.32-0.42$ \\
\hline Whey Proteins $(\mathrm{g} / 100 \mathrm{~g})$ & $0.49-0.80$ & $0.68-0.83$ \\
\hline
\end{tabular}

Table 1. Comparison of chemical composition and physical properties of donkey and human milk [27] (copyright permission obtained).

The donkey's three major whey proteins are $\alpha$-lactalbumin, $\beta$-lactoglobulin and lysozyme. Donkey's milk $\alpha$-lactalbumin has two isoforms with different isoeletric point [31]. Recently, it has been shown that $\alpha$-lactalbumin presents antiviral, antitumor, and anti-stress properties. In particular in human breast milk it was shown that the $\alpha$-lactalbumin forms a complex with oleic acid called HAMLET (Human Alpha-lactalbumin Made Lethal to Tumor cells) that proved to be able to induce tumour-selective apoptosis. This complex may be considered as a potential therapeutic agent against various tumour cells [32]. Furthermore it was shown that $\alpha$-lactalbumin possesses anti-inflammatory activity exerted by the inhibition of cyclooxygenase-2 (COX-2) and phospholipase A2 [33].

One of the main allergens in children is $\beta$-lactoglobulin that is the major whey protein in cow milk [17] while it is absent in human milk [34]. In donkey milk the content of $\beta$ lactoglobulin is approximately $40 \%$ of the whey proteins equal to the level in mare milk and lower than that in cow milk [34]. This condition may be related to the hypoallergenic characteristic of donkey milk $[1,12,35]$. The mechanism for tolerance may be related to the specific levels of the major allergenic components in the milk. Donkey's milk has three genetic variants for $\beta$-lactoglobulin: one presents three amino acid substitutions while the others have two amino acid exchanges [29]. Donkey milk $\beta$-lactoglobulin is a monomer whereas this protein is a dimer in ruminant's milk. $\beta$-lactoglobulin is a protein of the lipocalin family and has high affinity for a wide range of compounds opening the way to various suppositions about its function. In fact it has been shown that this protein is involved in hydrophobic ligand transport and uptake, enzyme regulation, and the neonatal acquisition of passive immunity, other authors demonstrated that $\beta$-lactoglobulin forms complexes with folic acid suggesting that these complexes could be used as an effective carrier of folic acid in functional foods [36].

The high content of lysozyme may be responsible for the low bacterial concentration in donkey milk $[4,5]$. Donkey milk lysozyme presents two isoforms that differ in three amino acid substitutions at position 48, 52 and 61 [29]. The concentration of lysozyme in human milk increases strongly after the second month of lactation, suggesting that this enzyme plays an important role in fighting infections in breast-fed infants during the late lactation [30]. 
The lactose content (7\%) of donkey milk is similar to that of human milk and is much higher if compared with cows milk. The high content is responsible for the good palatability and facilitates the intestinal absorption of calcium that is essential for infant's bone mineralization. Donkey milk shows a lower fat content compared to human milk, presenting for this reason a reduced energetic value [37]. The large number of fatty acids present in the lipid fraction of milk makes it one of the most complex naturally occurring fats. Saturated fatty acids are the most represented class in donkey's milk compared to monounsaturated and polyunsaturated fatty acids, even though a wide variability can be observed in the data available in literature, most likely related to dietary and/or body condition differences [4]. Within a well balanced and integrated diet, donkey's milk is a good source of essential fatty acids; this category of fatty acids are very important in the diet of patients with Cow Milk Allergy (CMA), especially if affected by multiple food allergy. These subjects are in fact at risk of developing a deficiency in essential fatty acids and particularly in PUFA $\mathrm{n}-3$, which are absolutely necessary for adequate growth, neurological development and cardiovascular health [38]. Donkey's milk shows an high content of both linoleic (C18:2) and linolenic (C18:3) acids, respectively $9.0 \mathrm{~g} / 100 \mathrm{~g}$ and 5.1 $\mathrm{g} / 100 \mathrm{~g}$ of total fatty acids, when compared with ruminant species milks, in which the contents of the above mentioned Polyunsaturated Fatty Acids are always lower. To increase the total fat content in donkey milk, clinical studies [17, 35] suggested to enrich donkey milk with medium-chain triglycerides, in order to obtain a final fat content similar to human milk.

The mineral composition is very close to that of human milk except for the highest level of calcium and phosphorus but the Ca-P ratio is similar. The milk produced in the first month of lactation, when it is the only nutritional source for the foal, contained the highest levels of mineral elements that may be related to the fast growth stage of the foal. Afterwards, the mineral supply in milk decreases considerably.

Basically, donkey milk has nutritional properties that make it more similar to human milk than another mammalian one. Therefore it could be used not only as a breast milk substitute for allergic children but also as a new dietetic food for human consumption. This chapter would be a further contribution to increase the characterization of donkey milk, evaluating the nutritional qualities of donkey milk using different proteomic approaches.

\section{Proteomic approaches}

The term proteome was introduced to describe "all proteins expressed by a genome or tissue [39]. Another definition of proteome, but similar, is: "a set of all expressed proteins in a cell, tissue or organism at a certain point in time" [40]. After genomics and transcriptomics, proteomics is considered the next and more articulate step in the study of biological systems. In fact, while the genome is more or less constant, any proteins may exist in multiple forms that vary from cell to cell and from time to time. In fact the proteome analysis reveals translational, post-translational modification, regulatory and degradation processes that affect protein structure, localization, function, and turnover. Proteomics is the 
study of multi-protein systems and their roles as part of a larger system or network. Therefore the context of proteomics is system biology, rather than structural biology, since it is a tool used to characterize the behaviour of the system rather than the behaviour of any single component.

Milk proteins have been studied in depth for well over 50 years and lot of studies were performed in order to analyse the various milk protein components, in various milk from different mammals. However, many questions concerning milk protein expression, structure and protein modifications remain still not completely covered such as some details of protein modifications due to disease and processing. The milk proteome is extremely complex because of the presence of post-translational modifications, alternative splicing and different genetic variants. The post-translational modifications are: glycosylation, phosphorylation, disulphide bonds formation and proteolysis, they create a large number of different protein variants from a single gene product. In milk the molecular composition of proteins is very important since it influences the functional properties of milk proteins such as solubility, clotting aptitude, thermal denaturation and the nutritional properties of the milk. Usually, the analytical procedures used for structural analysis of milk proteins are based on chromatographic techniques (ionic exchange, reversed phase chromatography, size-exclusion chromatography) followed by one-dimensional electrophoretic techniques (PAGE, Urea-PAGE and SDS-PAGE), or more efficiently on bi-dimensional electrophoresis technique (2-DE).

In our work we approached the study of donkey milk protein profile by different techniques for protein separation: initially they were based on chromatographic techniques followed by sodium dodecyl sulphate polyacrylamide gel electrophoresis SDS-PAGE [5]. Successively, the milk was analyzed through two-dimensional electrophoresis (2-DE) followed by $\mathrm{N}$ terminal sequencing, in order to give a more detailed panoramic view of the proteins that are present in donkey milk [41].

\subsection{Chromatographic approaches followed by SDS-PAGE}

Donkey's milk casein fraction was characterized by different chromatographic approaches using an Äkta Purifier HPLC system: ion-exchange chromatography, and reversed-phase. After chromatography, each protein was subjected to SDS-PAGE. The purified caseins were identified by N-terminal sequencing [5]. By cation-exchange chromatography (Mono S HR $5 / 5$ column, GE Healthcare, $1.0 \mathrm{ml}$ bed volume), performed at $\mathrm{pH} 5$ and 7, followed by $15 \%$ SDS-PAGE (Mini Protean III apparatus, Bio-Rad) it was possible to separate 9 peaks that were identified as $\beta$-caseins (sequence: REKEELNVSS) and $\alpha$ s1-caseins (sequence: RPKLPHRQPE), having different molecular weight, as shown in figure 1 and table 2.

Reversed-phase chromatography on HPLC (RP-HPLC) followed by $15 \%$ SDS-PAGE and Nterminal analysis was performed on the skimmed donkey's milk giving as a result three main peaks (K, L, M) identified as lysozyme (sequence, KVFSKXELA), $\alpha$-lactalbumin, (sequence, KQFTKXELSQVLXSM), and $\beta$-lactoglobulin (sequence TNIPQTMQ), respectively 


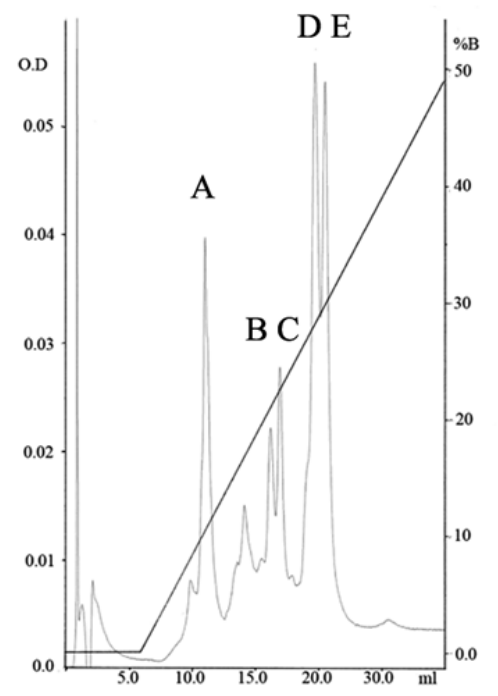

A

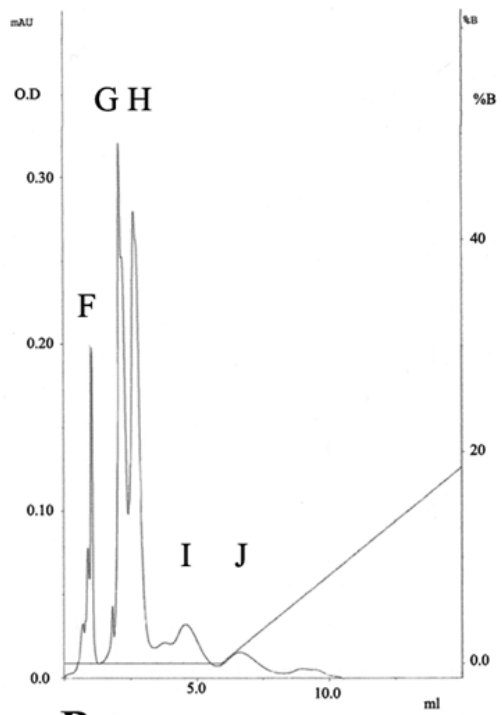

B

Figure 1. Cationic-exchange chromatography on HPLC (Mono S HR 5/5) analysis on whole casein performed at $\mathrm{pH} 5.5$ (A) and at $\mathrm{pH} 7.0$ (B) [5] (copyright permission obtained).

\begin{tabular}{|c|c|c|c|}
\hline Peak/Chromatography & Protein & $\mathrm{kDa}$ & N-terminal sequence \\
\hline A: cationic exchange, pH 5.5 & B-casein & 35.40 & REKEELNVS \\
\hline \multirow{2}{*}{ C, D, E: cationic exchange, pH 5.5 } & $\alpha$ s1-casein & 33.00 & RPKLPHRQPE \\
& $\alpha$ s1-casein & 30.70 & RPKLPHRQPE \\
\hline F: cationic exchange, pH 7.0 & B-casein & 33.30 & REKEELNVS \\
\hline G, H, I, J: & $\alpha$ s1-casein & 31.30 & RPKLPHRQPE \\
cationic exchange, pH 7.0 & $\alpha$ s1-casein & 29.40 & RPKLPHRQPE \\
\hline
\end{tabular}

(copyright permission obtained).

Table 2. Donkey's milk caseins identified by cationic exchange chromatography [5].

(Figure 2A and table 3). RP-HPLC was also performed on the donkey's milk casein fraction after their precipitation from skimmed milk at $\mathrm{pH}$ 4.6. Five peaks were recovered (N-R) each of them submitted to $13 \%$ SDS-PAGE and N-terminal analysis and the results, showed in figure $2 \mathrm{~B}$ and in table 3 , indicated mainly the presence of $\alpha \mathrm{S} 1$-caseins and $\beta$-caseins. Furthermore, the $\beta$-casein sequence of peak R (REKEALNV) showed an $\mathrm{E} \rightarrow \mathrm{A}$ substitution in the fifth aminoacid [5].

This study revealed the presence of $\beta$-caseins (sequence: REKEELNVSS) and $\alpha$ s1-caseins (sequence: RPKLPHRQPE), which presented marked homology with $\alpha \mathrm{s}_{1-}$ and $\beta$-caseins from mare's milk [42], while the presence of other types of caseins, such as $\alpha \mathrm{s} 2-^{-}, \gamma-$ and kwere not determined in donkey milk. This result show another high similarity between donkey and human milk: in fact, the presence of as2-caseins in human milk has not been demonstrated [34]. 


\begin{tabular}{|c|c|c|c|}
\hline Peak/RP-HPLC & Protein & $\mathrm{kDa}$ & N-terminal sequence \\
\hline $\mathrm{K}$ & Lysozyme & 14.60 & KVFSKXELA \\
\hline $\mathrm{L}$ & $\alpha$-lactalbumin & 14.12 & KQFTKXELSQVLXSM \\
\hline $\mathrm{M}$ & $\beta$-lactoglobulin & 22.40 & TNIPQTMQ \\
\hline $\mathrm{P}$ & $\alpha$ s1-casein & 33.30 & RPKLPHQPE \\
\hline $\mathrm{Q}$ & $\beta$-casein & 37.50 & REKEELNVS \\
\hline $\mathrm{R}$ & $\beta$-casein & 37.50 & REKEALNVS \\
\hline
\end{tabular}

Table 3. Donkey's milk protein fraction identified by reversed phase chromatography in HPLC (see also figure $2 \mathrm{~A}$ and B). [5] (copyright permission obtained).

A

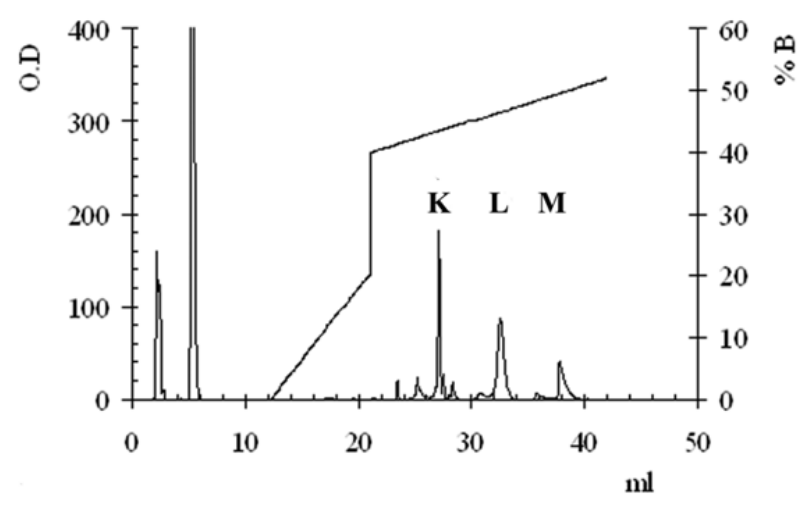

B

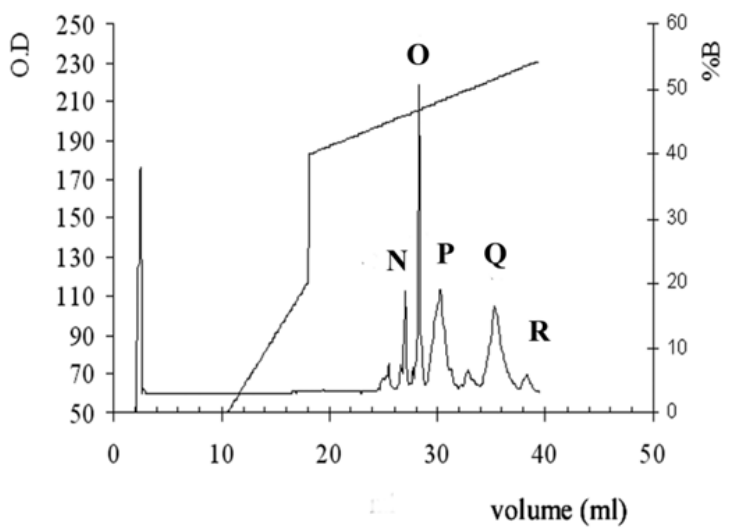

Figure 2. (A) Reversed-phase HPLC of: (A) skimmed donkey's milk and (B) casein fraction [5] (copyright permission obtained). 


\subsection{Quantitative determination of lysozyme, $\beta$-lactoglobulin, $\alpha$-lactalbumin and lactoferrin.}

Thanks to RP-HPLC analysis, it was possible also to calculate the lysozyme, $\beta$-lactoglubulin and $\alpha$-lactalbumin concentrations (in $\mathrm{mg} / \mathrm{ml})$ at different stages of lactation $(60,90,120,160$ and 190 days after parturition), the results are shown in Table 4.

\begin{tabular}{|c|c|c|c|}
\hline Days after parturition & Lysozyme $(\mathrm{mg} / \mathrm{ml})$ & $\beta$-lactoglobulin & $\alpha$-lactalbumin \\
\hline 60 & 1.34 & Not determined & 0.81 \\
\hline 90 & 0.94 & 4.13 & 1.97 \\
\hline 120 & 1.03 & 3.60 & 1.87 \\
\hline 160 & 0.82 & 3.69 & 1.74 \\
\hline 190 & 0.76 & 3.60 & 1.63 \\
\hline
\end{tabular}

Table 4. Quantitative determination of lysozyme, $\beta$-lactoglobulin, $\alpha$-lactalbumin in different stages of lactation [5] (copyright permission obtained).

The amount of lysozyme in donkey's milk varied considerably during the different stages of lactation, with a mean value of $1.0 \mathrm{mg} / \mathrm{ml}$, and proved to be higher with respect tothat in bovine (traces), human $(0.12 \mathrm{mg} / \mathrm{ml})$ and goat'smilk (traces), whereas, it was very close to mare's milk $(0.79 \mathrm{mg} / \mathrm{ml})$ [43]. The mean $\beta$-lactoglobulin content in donkey's milk (3.75 $\mathrm{mg} / \mathrm{ml})$ was very close to that of bovine milk $(3.3 \mathrm{mg} / \mathrm{ml})$ and pony mare's milk $(3.0 \mathrm{mg} / \mathrm{ml})$, whereas in human milk the $\beta$-lactoglobulin is absent [34]. The $\alpha$-lactalbumin content increased in the three months after parturition till the value of $1.8 \mathrm{mg} / \mathrm{ml}$, close to the $\alpha$ lactalbumin content in human milk $(1.6 \mathrm{mg} / \mathrm{ml})$ but lowest compared to the pony mare's $\alpha$ lactalbumin content $(3.3 \mathrm{mg} / \mathrm{ml})$ [5].

Lactoferrin was purified by a cationic exchange chromatography (Mono S HR5/5 column) and its identity was confirmed by N-terminal sequencing and by western blot analysis using anti-lactoferrin antibodies (see figure 3A) [41]. The quantitative determination of donkey's milk lactoferrin (Figure 3B) gave a result of $0.080 \pm 0.0035 \mathrm{~g} / \mathrm{L}$, similar to that found in mare $(0.1 \mathrm{~g} / \mathrm{L})$, cow $(0.02-0.2 \mathrm{~g} / \mathrm{L})$, goat $(0.06-0.40 \mathrm{~g} / \mathrm{L})$, and sheep milk $(0.135 \mathrm{~g} / \mathrm{L})$, but lower when compared with the lactoferrin content in human milk, in which values are usually in the range $1.0-6.0 \mathrm{~g} / \mathrm{L}[44,45]$.

Lactoferrin is an iron-binding protein that displays many biological functions: regulation of iron homeostasis, cellular growth, anti-microbial and anti-viral functions, and protection against cancer development and metastasis [46]. Lactoferrin exerts its antibacterial effect by two different mechanisms involving two separate domains of the protein. In the first one, the antimicrobial effect is due to the high iron binding affinity of the protein that deprives some iron-requiring bacteria of iron and consequently inhibits their growth $[46,47]$. The second antimicrobial property is due to the cationic domain at N-terminus directly responsible for the bactericidal effect [48]. 
$\mathbf{A}$

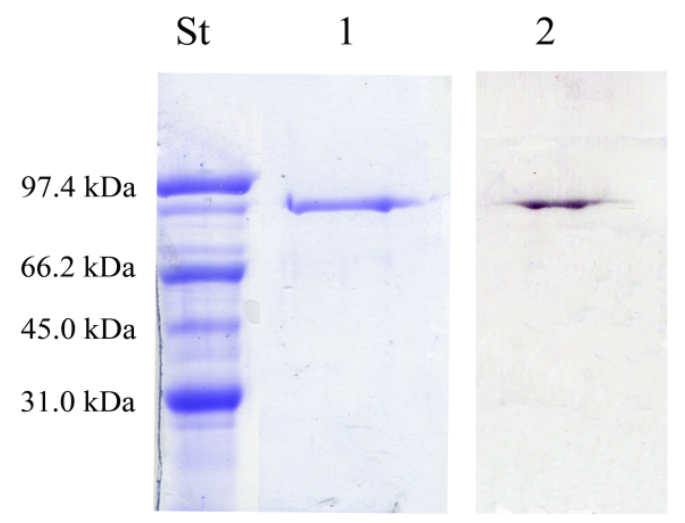

B

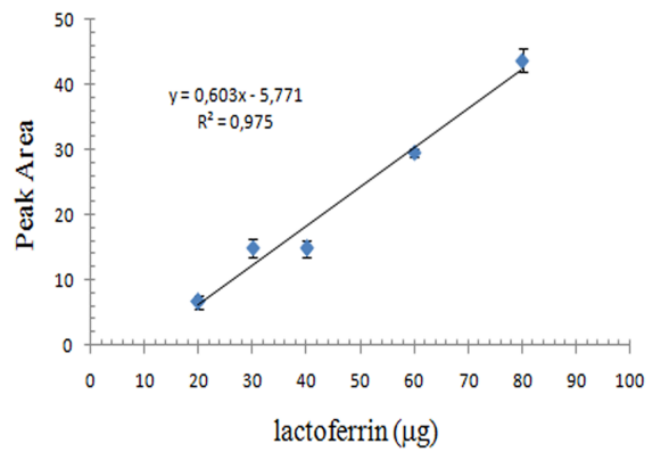

[41] (copyright permission obtained).

Figure 3. A) $12 \%$ SDS-PAGE (lane 1) and immunoblotting using anti-lactoferrin antibodies (lane 2) of lactoferrin purified by Mono S column. St: Bio-Rad low-molecular-weight standard (phosphorylase b, $97.4 \mathrm{kDa}$; bovine serum albumin, $66.2 \mathrm{kDa}$; ovalbumin $45.0 \mathrm{kDa}$; carbonic anhydrase, $31 \mathrm{kDa}$; soybean trypsin inhibitor, $21.5 \mathrm{kDa}$; lysozyme, $14.4 \mathrm{kDa}$.

B) Calibration line of standard solutions of lactoferrin (20-100 final $\mu \mathrm{g})$.

Lactoperoxidase is a glycoprotein consisting of a single peptide chain with a molecular weight of $78.0 \mathrm{kDa}$. This enzyme exerts its antimicrobial action through the oxidation of thiocyanate ions (SCN-) by hydrogen peroxide, both present in biological fluids and also in milk. Lactoperoxidase activity in skimmed donkey milk was evaluated by a continuous spectrophotometric rate determination using as substrate 2,2'-Azinobis (3-Ethylbenzthiazoline6-Sulfonic Acid) [49]. In donkey milk the activity of lactoperoxidase is very low, $4.83 \pm 0.35$ $\mathrm{mU} / \mathrm{mL}$. The enzyme quantification was achieved by a calibration line obtained by plotting the nanograms of peroxidase standard solutions against the enzymatic activity The mean $( \pm \mathrm{SD})$ concentration of donkey milk lactoperoxidase was calculated to be $0.11 \pm 0.027 \mathrm{mg} / \mathrm{L}$, close to 
the value obtained with human milk $(0.77 \pm 0.38 \mathrm{mg} / \mathrm{L})$ [50]. In table 5 the concentration of three proteins with antimicrobial effect are compared from donkey, human and cow milk. From these data is evinced that human and donkey milk contain considerable amounts of lysozyme and lactoferrin but lactoperoxidase is present only in small amounts.

\begin{tabular}{|c|c|c|c|}
\hline Milk & Lactoperoxidase $(\mathrm{mg} / \mathrm{L})$ & Lysozyme $(\mathrm{g} / \mathrm{L})$ & Lactoferrin $(\mathrm{g} / \mathrm{L})$ \\
\hline Human & 0.77 & 0.12 & $0.3-4.2$ \\
\hline Donkey & 0.11 & 1.0 & 0.080 \\
\hline Bovine & $30-100$ & trace & 0.10 \\
\hline
\end{tabular}

Table 5. Content of lactoperoxidase, lactoferrin and lysozyme from bovine, donkey and human milk [5, $50,51]$ (copyright permission obtained).

\subsection{Two-dimensional electrophoresis (2-DE) analysis}

Whole casein was obtained from skimmed milk by adjusting the $\mathrm{pH}$ to 4.6 with $10 \%(\mathrm{v} / \mathrm{v})$ acetic acid and centrifuging at $3000 x \mathrm{x}$ for $10 \mathrm{~min}$ in order to obtain a supernatant of whey proteins and the isoelectrically precipitated caseins. In the 2-DE analysis [41], the first dimension was an isoelectric focusing (IEF) performed using a pre-cast immobilized $\mathrm{pH}$ gradient gel strip Immobiline DryStrip, (IPG-strip, length $18 \mathrm{~cm}$ ) in the $\mathrm{pH}$ range of 4-7 for the casein fraction and in the $\mathrm{pH}$ range of 3-11 for the whey proteins. The second dimension, performed using a Protean II apparatus (Bio-Rad, $180 \times 200 \times 1.5 \mathrm{~mm}$ ), consisted of a 13\% SDS-PAGE for the casein fraction and a $15 \%$ or a $7.5 \%$ SDS-PAGE for the whey proteins. After staining, the gel were analyzed using PD-Quest software (Version 7.1.1; Bio-Rad) in order to define spot-intensity calibration, spot detection, background abstraction, calibration, and calculation of molecular mass and pI. The spots considered interesting and quantitatively significant were subjected to N-terminal analysis for their identification. The results of donkey milk 2-DE analysis is shown in figure 4.

The casein fraction ( $\mathrm{pH}$ range 4-7, figure 4) showed the presence of 13 major protein spots: eight of them were identified as $\beta$-caseins ( $N$-terminal sequence: RKEELNVSS) with a $\mathrm{pI}$ values ranging from 4.63 to 4.95 . Furthermore four $\beta$-caseins spots (from spot $A$ to $D$ ) showed molecular weights ranging from 33.10 to $33.74 \mathrm{kDa}$ whereas the other four $\beta$-caseins spots (from spot $\mathrm{E}$ to $\mathrm{H}$ ) displayed molecular weights ranging from 31.15 to $32.15 \mathrm{kDa}$, with a difference of about 1000 aminoacids. This results are in good agreement with [52] who demonstrated the presence of a full-length $\beta$-casein variant carrying 7, 6, 5 phosphate groups, with a pI of 4.74, 4.82, 4.91 respectively and a spliced variant (-923 aminoacids), carrying 7, 6, 5 phosphate groups with a $\mathrm{pI}$ of 4.64, 4.72, 4.80 respectively. On the basis of these observations, and looking at figure 4, it may be evinced that the spots B, C and D may correspond to the full-length forms of $\beta$-caseins (pI: 4.72, 4.82, 4.92 respectively) whereas the spots E, F, and G may correspond to the spliced variants of $\beta$-caseins (pI: 4.68, 4.80, 4.88). The other remaining five spots (from $\mathrm{I}$ to $\mathrm{N}$ ) were identified as $\alpha$ s1-caseins ( $\mathrm{N}$-terminal sequence: RPKLPHRPE) with a pI values ranging from 4.92 to 5.36 (see figure 4). In donkey milk an heterogeneity for the $\alpha$ s1-casein was found [52], assigned to either discrete 


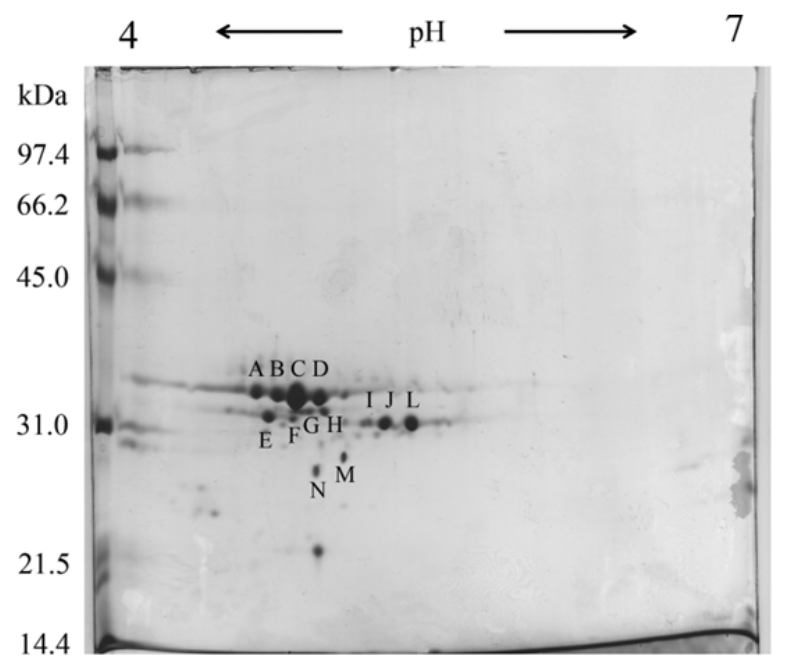

Figure 4. Two-dimensional electrophoresis analysis of donkey milk casein fraction. The first dimension was performed in the $\mathrm{pH}$ range of $4-7$, the second dimension consisted of a 13\%SDS-PAGE. St: Bio-Rad low molecular weight standard (phosphorylase b, $97.4 \mathrm{kDa}$; bovine serum albumin, 66.2 kDa; ovalbumin $45.0 \mathrm{kDa}$; carbonic anhydrase, $31 \mathrm{kDa}$; soybean trypsin inhibitor, $21.5 \mathrm{kDa}$; lysozyme, 14.4 $\mathrm{kDa}$ ). [41] (copyright permission obtained).

phosphorylation (5, 6 and 7 phosphate/mole) or non-allelic spliced forms. In our work we found in donkey milk five $\alpha$ s1-caseins: three of them showed a high molecular weight (about 31. $3 \mathrm{kDa}$ ) and probably correspond to the full-length phosphorylated forms, whereas two $\alpha$ s1- caseins showed a lowest molecular weight (about $28 \mathrm{kDa}$ ) therefore they may correspond to the spliced variants. In our study the presence of $\alpha$ s2-casein and $\kappa$-casein were not demonstrated probably because of their low amount in donkey milk. Another group of authors [53] identified in donkey milk the presence of a weak spot identified as $\alpha$ s2-casein and three very weak spots identified as $\kappa$-casein. Therefore, the heterogeneity shown in the whole casein analysis by 2-DE may be due to a variable degree of phosphorylation and to spliced forms of $\alpha$ s1- and $\beta$-caseins [54-56].

The whey fraction was analyzed by 2-DE in a $\mathrm{pH}$ range of 3-11 for the first dimension but with two different polyacrylamide gel percentages in the second dimension in order to have a better differentiation and identification of the low- and high-molecular weight whey proteins as shown in figure $5 \mathrm{~A}$ and $\mathrm{B}$.

The separation of low-molecular-weight whey proteins achieved by 2-DE (first dimension: IPG-strip, pH 3-11, second dimension: 15\% SDSPAGE) revealed the presence of two isoforms of $\alpha$-lactalbumin (Figure 5A) corresponding to the spots $\mathrm{R}$ and $\mathrm{S}$. This result is in agreement with [57] who observed oxidized methionine forms for $\alpha$-lactoalbumin (Met 90), due to in vivo oxidative stress that give rise to two $\alpha$-lactalbumin isoforms. Furthermore from 2-DE, three isoforms of donkey milk $\beta$-lactoglobulin (Figure $5 \mathrm{~A}$ ), corresponding to the spots $\mathrm{O}, \mathrm{P}$, and $\mathrm{Q}$, were observed. In this case from literature it is known that in donkey 


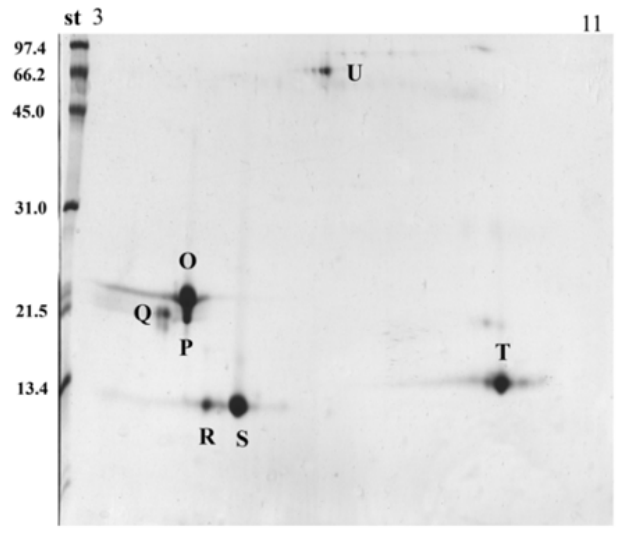

A

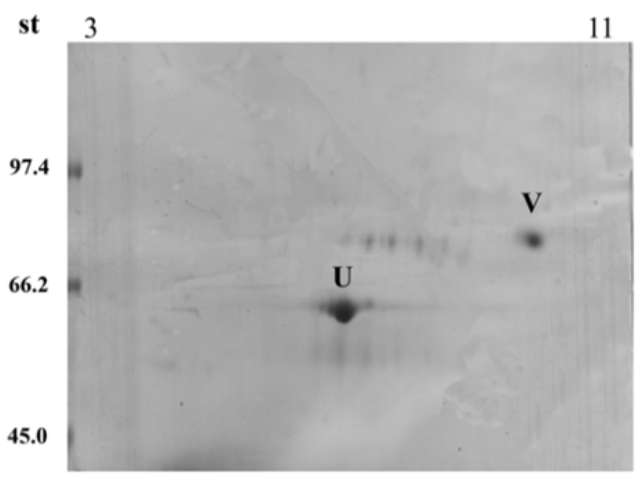

B

Figure 5. Two-dimensional electrophoresis analysis of donkey milk whey protein fraction. The first dimension was performed in the $\mathrm{pH}$ range of 3-11. The second dimension was carried out by: A) $15 \%$ SDS-PAGE for the identification of the low molecular weight whey proteins, B) $7.5 \%$ SDS-Page for the identification of high molecular weight whey proteins. The standard (st) was the same as figure 4. [41] (copyright permission obtained).

milk, this protein exists under two different forms, named $\beta$-lactoglobulin $\mathrm{I}$, that constitutes the major form $(80 \%)$, and $\beta$-lactoglobulin II $[58,59]$ that constitutes the minor form $(20 \%)$. Successively, a genetic variant for $\beta$-lactoglobulin I (named $\beta$-lactoglobulin I B) with three amino acid substitutions explained by the degeneracy of the genetic code was found [29], and two genetic variants for $\beta$-lactoglobulin II (named $\beta$-lactoglobulin II B and C). Successively another $\beta$-lactoglobulin II variant (named D) was detected as minor component in the whey fraction of donkey milk [57]. Finally, after 2-DE experiments, only one spot corresponding to donkey milk lysozyme was detected (Figure 5A, spot $\mathrm{T}$ ) even if from literature the presence of two donkey milk lysozyme genetic variants that arise from an oxidized methionine residue at position 79 [29, 57]. Finally, Figure 5B shows the electropherogram for the donkey milk high molecular-weight whey proteins separated by 2DE (first dimension: IPG-strip pH 3-11, second dimension: 7.5\% SDS-PAGE). By N-terminal sequencing it was possible to assign the spot $\mathrm{U}$ to serum albumin $(\mathrm{kDa} / \mathrm{pI}$ : 62.7/7.1) and the spot $\mathrm{V}$ to lactoferrin (kDa/pI: 77.0/9.8), already discussed in the section 5.2 [41].

\section{Conclusion}

Recent clinical evidence has renewed the interest in donkey milk because of high tolerability in infants with cows' milk protein allergy. To be successful as a substitute for human milk in infant nutrition, donkey milk must be capable of performing many biological functions associated with human milk. The specific protein fraction in donkey milk can be a good indicators of its potential role. In this study, donkey milk whey proteins were analyzed by 2-DE and were also quantified. From the proteomic map was revealed the presence of two isoforms of $\alpha$ lactalbumin, three isoforms of $\beta$-lactoglobulin, lysozyme, albumin and lactoferrin. 
The high lysozyme and $\alpha$-lactalbumin content found in donkey milk may be responsible for the low bacterial count reported in literature. Lysozyme, lactoperoxidase and lactoferrin have been recognized as antimicrobial and bacteriostatic agents and could be useful to prevent intestine infections in infants. Their action may extend the conservation of fresh donkey milk and the relative potential commercial supply.

On the basis of results obtained donkey milk may be considered suitable for feeding young children affected by severe cow's milk allergy. In the past it has been widely used to replace human milk because its chemical composition and particularly protein content are close to that of human. Great attention must be obviously given to the hygienic characteristics of donkey milk production, in order to consider this milk a valid substitute of hydrolysed proteins or soy-bean derived formulae in the treatment of infants with cow's milk protein allergy.

Food is called functional if it contains one or more components that can provide a benefit to human health, beyond their traditional nutritional role. Donkey milk may be configured as functional food in early childhood and not only.

\section{Author details}

Paolo Polidori and Silvia Vincenzetti

Università di Camerino, Italy

\section{References}

[1] Carroccio A, Cavataio F, Montalto G, D'Amico D, Alabrese L, Iacono G (2000) Intolerance to hydrolysed cow's milk proteins in infants: clinical characteristics and dietary treatment. Clin. Exp. Allergy 30: 1597-1603.

[2] Monti G, Bertino E, Muratore MC, Coscia A, Cresi F, Silvestro L, Fabris C, Fortunato D, Giuffrida MG, Conti A (2007) Efficacy of don key's milk in treating highly problematic cow's milk allergic children: an in vivo and in vitro study. Pediatr. Allergy Immun. 18: 258-264.

[3] Polidori P, Beghelli D, Mariani P, Vincenzetti S (2009) Donkey milk production: state of the art. Ital. J. Anim. Sci. 8(Suppl. 2): 677-683.

[4] Salimei E, Fantuz F, Coppola R, Chiofalo B, Polidori P, Varisco G (2004) Composition and characteristics of ass's milk. Anim. Res. 53: 67-78.

[5] Vincenzetti S, Polidori P, Mariani P, Cammertoni N, Fantuz F, Vita A (2008) Donkey's milk protein fractions characterization. Food Chem. 106: 640-649.

[6] Pacheco MTB, Costa Antunes AE, Sgarbieri VC (2008) New Technological and physiological functional properties of milk proteins. In: Boscoe AB, Listow CR, editors, Protein Research Progress. 117-168, New York: Nova Science Publishers Inc. pp. 117168.

[7] Ng-Kwai-Hang KF (2003) Milk proteins - Heterogeneity, Fractionation and Isolation. In: Roginski H, Fuquay JW, Fox PF, editors, Encyclopedia of Dairy Sciences. London: Academic Press. pp. 1881-1894. 
[8] Schanbacher FL, Talhouk RS, Murray FA, Gherman LI, Willett LB (1998) Milk-borne bioactive peptides. Int. Dairy J. 8: 393-403.

[9] Tanaka T (2007) Antimicrobial activity of lactoferrin and lactoperoxidase in milk. In: Ling JR, editor, Dietary Proteins Research Trends. New York: Nova Science Publishers Inc. pp. 101-115.

[10] Bjorck L (1978) Antibacterial effect of the lactoperoxidase system on psychotrophic bacteria in milk. J. Dairy Res. 45: 109-118.

[11] Vincenzetti S, Polidori P, Vita A (2007) Nutritional characteristics of donkey's milk protein fraction. In: Ling JR, editor, Dietary Proteins Research Trends. New York: Nova Science Publishers Inc. pp. 207-225.

[12] Businco L, Gianpietro PG, Lucenti P, Lucaroni F, Pini C, Di Felice G, Iacovacci P, Curadi C, Orlandi M (2000) Allergenicity of mare's milk in children with cow's milk allergy. J. Allergy Clin. Immunol. 105: 1031-1034.

[13] McClenathan DT, Walker WA (1982) Food allergy. Cow milk and other common culprits. Postgraduate Medicine 72: 233-239.

[14] Park YW, Haenlein GFW (2006) Therapeutic and hypoallergenic values of goat milk and implication of food allergy. In: Park YW, Haenlein GFW, editors. Handbook of milk of non-bovine mammals. Oxford: Blackwell Publishing. pp. 121-135.

[15] Park YW (1994) Hypo-allergenic and therapeutic significance of goat milk. Small Rumin. Res. 14: 151-159.

[16] El-Agamy EI (2007) The challenge of cow milk protein allergy. Small Rumin. Res. 68: 6472.

[17] Carroccio A, Cavataio F, Iacono G (1999) Cross-reactivity between milk proteins of different animals. Clin. Exp. Allergy 29: 1014-1016.

[18] Docena GH, Ferandez R, Chirdo FG, Fossati CA (1996) Identification of casein as the major allergenic and antigenic protein of cow's milk. Allergy 51: 412-416.

[19] Heyman M, Desjeux JF (1992) Significance of intestinal food protein transport. J. Pediatr. Gastroent. Nutr. 15: 48-57.

[20] Sampson HA (2004) Update on food allergy. J. Allergy Clin. Immunol. 113: 805-819.

[21] Hill DJ, Hosking CS (1996) Cow milk allergy in infancy and early childhood. Clin. Exp. Allergy 26: 254-261.

[22] Stintzing G, Zetterstrom R (1979) Cow's milk allergy, incidence and pathogenetic role of early exposure to cow's milk formula. Acta Paediatr. Scandin. 68: 383-387.

[23] Bock SA (1987) Prospective appraisal of complaints of adverse reactions to foods in children during the first 3 years of life. Paediatrics 79: 683-688.

[24] Host A, Husby S, Osterballe O (1988) A prospective study of cow's milk allergy in exclusively breast-fed infants. Incidence, pathogenic role of early exposure to cow's milk formula, and characterization of bovine milk protein in human milk. Acta Paediatr. Scandin. 77: 663-670.

[25] Host A, Halken S (1990) A prospective study of cow's milk allergy in Danish infants during the first 3 years of life. Clinical course in relation to clinical and immunological type of hypersensitivity reaction. Allergy 45: 587-596. 
[26] Restani P, Beretta B, Fiocchi A, Ballabio C, Galli CL (2002) Cross-reactivity between mammalian proteins. Ann. Allergy Asthma Immunol. 89(Suppl.): 11-15.

[27] Guo HY, Pang K, Zhang XY, Zhao L, Chen SW, Dong ML, Ren FZ (2007) Composition, Physiochemical properties, nitrogen fraction distribution, and amino acid profile of donkey milk. J. Dairy Sci. 90: 1635-1643.

[28] Malacarne M, Martuzzi F, Summer A, Mariani P (2002) Protein and fat composition of mare's milk: Some nutritional remarks with reference to human and cow's milk. Intern. Dairy J. 12: 869-877.

[29] Herrouin M, Mollé D, Fauquant J, Ballestra F, Maubois JL, Léonil J (2000) New genetic variants identified in donkey's milk whey proteins. J. Protein Chem. 19: 105-115.

[30] Uniacke-Lowe T, Huppertz T, Fox PF (2010) Equine milk proteins: chemistry, structure and nutritional significance. Intern. Dairy J. 20: 609-629.

[31] Giuffrida MG, Cantisani A, Napoletano L, Conti A, Godovac-Zimmerman J (1992) The amino-acid sequence of two isoforms of $\alpha$-lactalbumin from donkey (Equus asinus) milk is identical. Biol. Chem. Hoppe-Seyler 373: 931-935.

[32] Zhang M, Yang F Jr, Yang F, Chen J, Zheng CY, Liang Y (2009) Cytotoxic aggregates of alpha-lactalbumin induced by unsaturated fatty acid induce apoptosis in tumor cells. Chem. Biol. Interactions 180: 131-142.

[33] Yamaguchi M, Yoshida K, Uchida M (2009) Novel functions of bovine milk derived alpha-lactalbumin: anti-nociceptive and anti-inflammatory activity caused by inhibiting cyclooxygenase-2 and phospholipase A2. Biol. Pharm. Bull. 32: 366-371.

[34] Miranda G, Mahé MF, Leroux C, Martin P (2004) Proteomic tools to characterize the protein fractions of Equidae milk. Proteomics 4: 2496-2509.

[35] Iacono G, Carroccio A, Cavataio F, Montalto G, Soresi M, Balsamo V (1992) Use of ass's milk in multiple food allergy. J. Pediatric Gastroent. Nutr. 14: 177-181.

[36] Liang L, Tajmir-Riahi HA, Subirade M (2008) Interaction of beta-lactoglobulin with resveratrol and its biological implications. Biomacromolecules 9: 50-56.

[37] Dugo P, Kumm T, Lo Presti M, Chiofalo B, Salimei E, Fazio A, Cotroneo A, Mondello L. (2005) Determination of tryacylglycerols in donkey milk by using high performance liquid chromatography coupled with atmospheric pressure chimica ionization mass spectrometry. J. Sep. Sci. 28: 1023-1030.

[38] Aldamiz-Echevarria L., Bilbao A, Andrade F, Elorz J, Prieto JA, Rodriguez-Soriano J (2008) Fatty acid deficiency profile in children with food allergy managed with elimination diets. Acta Paediatr. 97: 1572-1576.

[39] Wilkins MR, Appel RD, Williams KL, Hochstrasser DF (2007) Proteome research: concepts, technology and application. Berlin: Springer-Verlag, $240 \mathrm{p}$.

[40] Pennington SR, Wilkins MR, Hochstrasser DF, Dunn MJ (1997) Proteome analysis: from protein characterization to biological function. Trends Cell Biol. 7: 168-173.

[41] Vincenzetti S, , Amici A, Pucciarelli S, Vita A, Micozzi D, Carpi FM, Polzonetti V, Natalini P, Polidori P (2012) A Proteomic Study on Donkey Milk. Biochem. Anal. Biochem. Available: http://dx.doi.org/10.4172/2161- 1009.1000109. 
[42] Egito AS, Miclo L, Lopez C, Adam A, Girardet JM, Gaillard JL (2002) Separation and characterization of mare's milk $\alpha \mathrm{s}_{1}-, \beta-, \mathrm{k}$-caseins, $\gamma$-casein-like and proteose peptone component 5-like peptides. J. Dairy Sci. 85: 697-706.

[43] Stelwagen K (2003) Milk protein. In: Roginski H, Fuquay JW, Fox PF, editors. Encyclopedia of Dairy Sciences. London: Academic Press. pp 1835-1842.

[44] Hennart PF, Brasseu DJ, Delogne-Desnoeck JB, Dramaix MM, Robyn CE (1991) Lysozyme, lactoferrin, and secretory immunoglobulin A content in breast milk: Influence of duration of lactation, nutrition status, prolactin status, and parity of mother. Amer. J. Clin. Nutrit. 53: 32-39.

[45] Kanyshkova TG, Buneva VN, Nevinsky GA (2001) Lactoferrin and its biological functions. Biochem. (Moscow) 66: 1-7.

[46] Ward PP, Paz E, Conneely OM (2005) Multifunctional roles of lactoferrin: a critical overview. Cell. Molecular Life Sci. 62: 2540-2548.

[47] Valenti P, Antonini G (2005) Lactoferrin: an important host defense against microbial and viral attack. Cell. Molecular Life Sci. 65: 2576-2587.

[48] Bellamy W, Takase M, Yamauchi K, Wakabayashi H, Kawase K, Tomita M (1992) Identification of the bactericidal domain of lactoferrin. Biochem. Biophys. Acta 1121: 130-136.

[49] Pruitt KM, Kamau DN. (1993) Indigenous Antimicrobial Agents of Milk. In: International Dairy Federation Editions. Bruxelles: IDF. pp. 73-87.

[50] Shin K, Hayasawa H, Lönnerdal B (2001) Purification and quantification of lactoperoxidase in human milk with use of immunoadsorbent with antibodies against recombinant human lactoperoxidase. Amer. J. Clin. Nutrit. 73: 984-989.

[51] Masson PL, Heremans JF (1971) Lactoferrin in milk from different species. Comp. Biochem. Physiol. 39: 119-129.

[52] Chianese L, Calabrese MG, Ferranti P, Mauriello R, Garro G, De Simone C, Quarto M, Addeo F, Cosenza G, Ramunno L (2010) Proteomic characterization of donkey milk “caseome". J. Chrom. A 1217: 4834-4840.

[53] Bertino E, Gastaldi D, Monti G, Baro C, Fortunato D, Perono Garoffo L, Coscia A, Fabris C, Mussap M, Conti A (2010) Detailed proteomic analysis on DM: insight into its hypoallergenicity. Frontieres in Biosciences E2: 526-536.

[54] Visser S, Jenness R, Mullin RJ (1982) Isolation and characterization of $\beta$ - and $\gamma$-caseins from horse milk. Biochem. J. 203: 131-139.

[55] Ochirkhuyag B, Chobert JM, Dalgarrondo M, Haertlè T (2000) Characterization of mare caseins. Identification of $\alpha$ s1- and $\alpha$ s2-caseins. Lait 80: 223-235.

[56] Criscione A, Cunsolo V, Bordonaro S, Guastella AM, Saletti R, Zuccaro A, D’Urso G, Marletta D (2009) Donkey milk protein fraction investigated by electrophoretic methods and mass spectrometry analysis. Intern. Dairy J. 19: 190-197.

[57] Cunsolo V, Saletti R, Muccilli V, Foti S (2007) Characterization of the protein profile of donkey's milk whey fraction. J. Mass Spectrom. 42: 1162-1174.

[58] Godovac-Zimmermann J, Conti A, James L, Napolitano L (1988) Microanalysis of the amino-acid sequence of monomeric beta-lactoglobulin I from donkey (Equus asinus) 
milk. The primary structure and its homology with a superfamily of hydrophobic molecule transporters. Biol. Chem. Hoppe-Seyler 369: 171-179.

[59] Godovac-Zimmermann J, Conti A, Sheil M, Napolitano L (1990) Covalent structure of the minor monomeric beta-lactoglobulin II component from donkey milk. Biol. Chem. Hoppe-Seyler 371: 871-879. 